\title{
Tutkimuksen keskiössä oppiva aikuinen
}

\author{
Kauppi, A. \& Kontiainen, S. \& Nurmi, K.E. \& Tuomisto, J. \& Vaherva, T. (toim.) 1995. \\ Adult Learning in a Cultural Context. Adult and Continuing Education Research in \\ Finland. Finnish Adult Education Research Society in Finland and University of Helsinki, \\ Lahti Research and Training Centre.
}

Aikuiskasvatuksen Tutkimusseuran ja Helsingin yliopiston Lahden tutkimus- ja koulutuskeskuksen julkaisema "Adult Leaming in a Cultural Context. Adult and Continuing Education Research in Finland" esittää state-of-the-art -kokoelman suomalaisesta aikuiskoulutuksen tutkimuksesta. Kirja on tervetullut esittelyteos ulospäin ja myös kotimarkkinoille, tarjoten monipuolista luettavaa aikuiskoulutuksesta kiinnostuneille. Tällaista kokoelmaa on kaivattu myös aikuiskoulutuksen opintoihin.

Tarkastelen teosta sen välittämän yleiskuvan kautta, koska 29 artikkelin yksittäiskäsittely on tilaan nähden mahdotonta. Paitsi laaja, kokoelma on myös edustava, vaikkakin siitä mainitaan puuttuvaksi kaksi merkittävää aikuiskoulutukseen liittyvää tutkimusalaa, Helsingin kehittävä työntutkimus sekä Turun yliopiston koulutussosiologien ryhmä. Kirja antaa kuitenkin kattavan kuvan nimenomaisen aikuiskoulutustutkimukseksi leimautuvan tutkimusintressin sisällöstä, ja sellaisena sitä tarkastelen.

\section{Ryhmittely ja tarkastelutasot}

Artikkelit on ryhmitelty neljään ryhmään, joista yhtä nimetään sovelluksiksi ja kolmea muuta aikuiskoulutuksen eri konteksteiksi. Tämä on sikäli harhaanjohtavaa, että mainitut tarkastelutasot ("kulttuurinen konteksti", "elämänhistorian, ryhmän ja henkilökohtainen konteksti" sekä "työkonteksti") edustavat melko lailla eri ilmiö tasoja, ts. eri tasoisia käsitteellistyksiä, Kirjan nimessä on samoja ongelmia.

Kulttuurisen kontekstin käsite tai kulttuurintutkimus ei sinänsä jäsennä artikkeleja. Kulttuuri tematisoituu varsinaisesti lähinnä Soila Judén-Tupakan koulutusantropologisessa artikkelissa. Nimessä haetaankin ilmeisesti lähinnä tapaa puhua kokoavasti siitä, että aikuiskoulutusta tapahtuu eri tavoin, ihmiset antavat sille erilaisia merkityksiä, oppivat erilaisia asioita koulutuksessa tai sen ulkopuolella ja että aikuiskoulutus yhteiskunnallisena käytäntönä on erityyppisten intressien ja voimien suuntaamaa ja muotoutuu eri yhteiskunnissa erityisillä tavoilla. Nämä näkökulmat välittyvätkin, demonstroiden aikuiskoulutustutkimuksen monialaisuutta ja vahvaa jalansijaa Suomessa.

Ryhmien esittelytekstit referoivat artikkeleita, mutteivät tarjoa kehittelyä tai kokoavia arvioita osion teemasta. Pelkkä referointi tuntuu hieman turhalta, koska kirjan lopussa on abstraktit artikkeleista kirjoittajien esittelyjen lisäksi. Tämäntapaiset ryhmittelyt mikro-, meso- ja makrotason ilmiöihin eivät ehkä ole erityisen hedelmällisiä, koska näin ryhmiteltyjen artikkelien välille ei synny keskustelua. Kyse on kuitenkin myös siitä, että kiila on kooste melko laajan suomalaisten ja eurooppalaisten aikuiskoulutustutkijoiden kokouksen yhteydessä esitettyjä papereita. Niiden paljous ja monimuotoisuus tuottaa pakosta kirjon, jonka keskusteluttaminen lienee vaikeata. Tällaisenaan ryhmittely kuitenkin toimii tekstien ryhmittäjänä.

\section{Oppimisprosessit}

Aikuiskoulutustutkimusta yhdistää tietty tapa tarkastella yhteiskunnallisia ja yhteisöllisiä ongelmia. Kun ongelma nähdään aikuiskoulutuksellisena, huomio suunnataan yksilöiden tai joissain tapauksissa yhteisöjen oppimisprosessiin ja -toimintaan, sen seurauksiin sekä tämän prosessin vaihteleviin taustatekijöihin.

Oppiva aikuinen on suomalaisen aikuiskoulutustutkimuksen keskiössä, erityisesti kokemuksiaan reflektoivana ja oppimisen kautta emansipoituvana yksilönä. Samalla näkyy tietty realismin vaatimus: halutaan selvästi erottaa käsitteellisesti ja empiirisesti todellinen oppiminen ja todella aikaansaadut seuraamukset aiotusta oppimisesta tai tarjotusta koulutuspanoksesta. Tämän vuoksi useissa yhteyksissä tematisoidaankin mieluummin oppimista kuin kouluttamista, myös muistuttamaan, ettei oppiminen edes laadukas oppiminen - ilmiönä rajoitu formaaleihin tai suunniteltuihin opiskelu- tai opetustilanteisiin. 


\section{Tutkimus ja työelämän muutos}

Toinen vahva painotus on halu osallistua yhteiskunnallisen, erityisesti työelämän muutoksen ymmärtämiseen ja suuntaamiseen koulutusnäkökulmasta. Potentiaalisesti oppiva ja aktiivinen aikuinen on ydinidea, jonka avulla lähestytään mm. työelämän, organisaatioiden kehittämisen, kehitysyhteistyön ja työvoiman liikkuvuuden ongelmia. Erityisesti korostetaan yhteiskunnallisten muutosten edellyttämää vaatimusta oppia yleisiä, muuttuviin tilanteisiin varustavia toiminta- ja oppimisvalmiuksia ammattispesifien tietojen sijasta. Oppimisnäkökulma näyttää tulleen paradigmaattiseksi tavaksi ymmärtää ja jäsentää organisaatioiden ja jopa koko yhteiskunnan selviytymisen ongelmia tietointensiivistyvässä ja automatisoituvassa ympäristössä, ja tämä näkyy kautta linjan erityisesti työelämän ja organisaatioiden ongelmia ruotivassa kiilan loppupuoliskossa.

Kolmantena on mukana näkökulma, jossa aikuiskoulutus on itse tutkittavana ja selitettävänä käytäntönä ja yhteiskunnissa eri tavoin kehittyvänä instituutiona. Neljänneksi, oppivat aikuiset ovat aikuiskoulutuksen "kohdeanalyysin" kohteina, eli heitä, heidän kykyjään, motivoitumistaan tai opiskelukokemuksiaan tarkastellaan suhteessa heidän rooliinsa potentiaalisina opiskeluun osallistujina tai elinikäisesti oppivina kansalaisina.

Oppimisen tarkastelu näyttää olevan siirtymässä suuntaan, jossa se pyritään määrittelemään kulttuurisesti ja sosiaalisesti välittyneenä prosessina, joka toteutuu yksilöiden elämänhistoriallisessa ajassa, heidän elämänsä yhtenä toimintana työn ja vapaa-ajan ohella/osana, ja jossa tällöin yksilöiden itsensä oppimiselleen antama merkitys on relevantti näkökulma.

Itseohjautuvuus, reflektiivisyys ja kokemuksellisuus toistuvat suosittuina, hiukan rutiininomaisina aikuisoppimisen luonnehdintoina Mezirow'ta mukaillen.

Oppimisen laatuihin otetaan usein normittava, moraalinenkin kanta. Aikuisen tulee ja on oikeus eri ympäristöissä jatkuvasti oppia tulkitsemaan kokemuksiaan, ja oppimisen tulee olla nimenomaan "emansipatorista", eli transformoida oppimisen kokemuksellista kontekstia sekä oppijan käsitysten ja emotionaalisten reaktioiden perustoja. Normatiivinen lähestymistapa oppimiseen viedään äärimmilleen psykoanalyyttisten ideoiden sovelluksessa rellektoinnin opettelemiseen opettajankoulutuksen ryhmäprosesseissa (Ojanen \& Keskiluopa).

\section{Yksilösuuntautunut perusta}

Toisaalta oppiminen nähdään enenevästi organisaatioiden tehtävänä ja yhteisöt siten oppimisen subjekteina. Käsitteellistämistyö on hieman terävämpää muutamissa tätä kuvaavissa artikkeleissa (mm. Kauppi). Tämä saattaa johtua siitä, että oppivan subjektin radikaali uudelleenmäärittely pakottaa selkeämpiin ilmiötasojen rajauksiin. Vaikuttaa kuitenkin, että suomalainen aikuiskoulutustutkimus nousee yksilö-orientoituneesta maaperästä, vaikka sosiaalitieteiden diskurssi- ja konstruktionismi-innostuksen jälkimainingit tuntuvat nyt tarpeena suhteuttaa aikuisia eri sosiaalisiin ja biografisiin ympäristöihinsä ja nähdä heidät nimenomaan todellisuutensa aktiivisina konstruoijina. Suhteessa tähän koulutusta tarkastellaan toimintana, jonka tulisi emansipoida ja mahdollistaa kriittistä toimintaa ja itseohjautuvuuden yleisvalmiuksien kehittymistä.

Toisaalta myös työtoiminnan odotetaan mahdollistavan jatkuvia oppimiskokemuksia pysyäkseen yksilön kannalta merkityksellisenä. Näin ei useinkaan tapahdu, kuten monet kirjan artikkelit osoittavat. Mutta tämä ei ole ainakaan vielä saanut tutkijoita kääntämään analysoivaa katsetta jatkuvan, kaikkialla potentiaalisesti läsnäolevan ja siirtovaikutuksiltaan rajattoman oppimisen ideaalityyppiin tutkimuksen ohjaavana intressinä. Marjo Vuorikosken artikkeli kouluttajatahon intressien merkityksestä sosiaalityön profession kehityksessä tarjoaa ideoita, joille soisi kantavuutta. Mikä olisi aikuiskoulutustutkimuksen osuus sen tarkastelemien ilmiöiden institutionalisoimisessa?

Monissa teksteissä on leimallinen pyrkimys kokoavien skeemojenluomiseen. Aikuiskoulutustutkimus on perinteisesti pyrkinyt mikro-makronäkökulmien syntetisoimiseen ja välittävien käsitteiden löytämiseen (mm. Nurmi \& Kontiainen). Yleisesti suunta on pragmaattinen ja joissain tapauksissa myös evaluoiva. Pragmaattisuus on ilmeisintä interventioihin pyrkivissä hankkeissa, mutta sovellettavuusintressi on implisiittisenä läsnä laajemminkin. Tästäkö syystä perusteellisempia teoreettisia paikannuksia ja metodologista keskustelua lievästi vierastetaan? Tästä vaikutelmasta poikkeavat tosin jotkut niistä artikkeleista, joissa on valittu jonkin lähitieteen tai rajatun ilmiöalueen näkökulma, kuten kehityspsykologian (Llorente), oppimisprosessin mallintamisen (Poikela), sosiologian tai sosiohistorian (mm. Kantasalmi, Lahti). Varsinaista metodologista keskustelua käydään hyvin vähän, tässä lähinnä triangulaation ongelmista Jari Eskolan artikkelissa avoimen korkeakoulun opiskelijoiden opiskelumotivaation kehityksestä. 
Hedelmällisin keskustelu aikuiskasvatuksen tutkimuksessa syntynee pragmaattisen ja analyyttisen näkökulman vuoro-puhelusta, jollaista tämänkin kokoelman lukija voi kutoa tekstien välille. Uskon sen olleen myös artikkelit tuottaneen kokouksen' antina. Tästä osoituksena pitäisin toisaalta teksteissä näkyvää pyrkimystä osallistua suunniteltuun muutokseen ja visiointiin kansainvälistyvässä suomalaisessa yhteiskunnassa, toisaalta jatkuvaa, ehkä "tieteen sisäisempää", pyrkimystä lähestyä aikuisten elämismaailman rajaamaa todellisuutta ja sen rakentumista eli käytännöissä.

Sanna Vehviläinen 